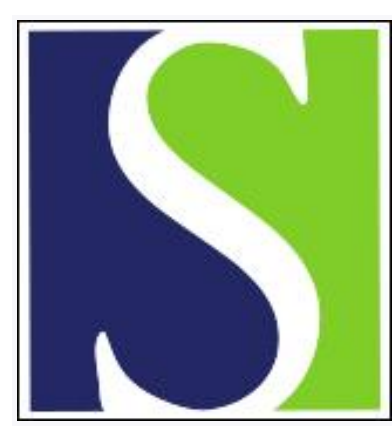

Scand J Work Environ Health 2000;26(3):250-256

https://doi.org/10.5271/sjweh.539

Issue date: Jun 2000

Cellulase allergy and challenge tests with cellulase using immunologic assessment

by Vanhanen M, Tuomi T, Tupasela O, Keskinen H, Tuppurainen M, Hytönen M, Tarvainen K, Kanerva L, Nordman H

Key terms: chamber challenge; enzymes; occupational asthma; occupational rhinitis

This article in PubMed: www.ncbi.nlm.nih.gov/pubmed/10901118

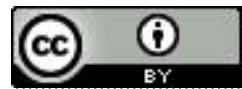




\title{
Cellulase allergy and challenge tests with cellulase using immunologic assessment
}

\author{
by Markku Vanhanen, MD, ${ }^{1}$ Timo Tuomi, PhD, ${ }^{1}$ Outi Tupasela, MSc, ${ }^{1}$ Helena Keskinen, MD, ${ }^{1}$ Matti \\ Tuppurainen, MD, ${ }^{1}$ Maija Hytönen, $M D,{ }^{2}$ Kyllikki Tarvainen, $M D,{ }^{3}$ Lasse Kanerva, MD, ${ }^{1}$ Henrik Nordman, \\ $M D^{1}$
}

\begin{abstract}
Vanhanen M, Tuomi T, Tupasela O, Keskinen H, Tuppurainen M, Hytönen M, Tarvainen K, Kanerva L, Nordman H. Cellulase allergy and challenge tests with cellulase using immunologic assessment. Scand J Work Environ Health 2000;26(3):250-256.
\end{abstract}

\begin{abstract}
Objectives This study attempted to develop and evaluate a challenge test for diagnosing allergic asthma and rhinitis due to cellulase.

Methods Challenge tests in a chamber were performed on 11 persons sensitized to cellulase. Four different enzyme-lactose mixtures, starting from a $0.03 \%$ mixture, were used. The enzyme dust was generated from a dry enzyme preparation mixed with lactose powder, using pressurized air. The cellulase concentration in the air was measured with an immunochemical method.

Results Nasal, pharyngeal, or bronchial symptoms could be elicited at cellulase air concentrations of 1 to 1300 $\mu \mathrm{g} / \mathrm{m}^{3}$. A dose-response relationship was observed for symptoms in repeated challenge tests with increasing concentrations of cellulase. For 2 persons skin symptoms could also be reproduced.

Conclusion The challenge method proved to be a practical means with which to simulate conditions at the worksite and elicit the specific respiratory symptoms of the patients.
\end{abstract}

Key terms chamber challenge, enzymes, occupational asthma, occupational thinitis.

The use of industrial enzymes has increased rapidly during the past 20 years $(1,2)$. Cellulases and hemicellulases are capable of degrading constituents of plants. They are used in pulp and paper, foodstuffs, and animal feed, as well as in the textile industry. The main cellulase enzymes are cellobiohydrolases, endoglucanases, and $\beta$-glucosidases, while xylanases are industrially the most important of the hemicellulases (1).

Since the late 1960s, several enzymes have been shown to cause occupational allergies (2). Allergy due to cellulase was first described in 1981 by Ransom \& Schuster (3). The patient was a scientist working on plant cloning experiments. Since then, cellulase allergy has been reported, for example, in the pharmaceutical industry (4), in enzyme production (5) and in bakery work (6).

Allergies due to cellulase have been increasing in Finland during the past 10 years (7). This trend is in accordance with the rapidly growing production of cellulolytic enzymes in Finland in recent years. A considerable part of the enzyme is dried and is thus handled in powder form in the workplaces, especially in the enzyme factories. Knowledge of the sensitizing properties of these enzymes had been deficient in the workplaces in the first years of production, and this lack probably explains why the air concentrations of enzymes were probably high in many parts of the process. Later, industrial hygiene was improved (7).

The accuracy of the diagnostics of occupational respiratory diseases has been emphasized in the literature $(8,9)$. Challenge methods constitute an important part of the specific diagnostics. A variety of bronchial challenge test settings have been described for different enzymes $(4,6,9-15)$. Local nasal challenges have also been performed (16). Cellulase challenge tests have been described by Losada et al (4), Quirce et al (6) and Merget et al (9).

In this report we present our experiences in diagnosing allergic occupational respiratory diseases caused by

1 Finnish Institute of Occupational Health, Helsinki, Finland.

2 Helsinki University Central Hospital, Department of Otorhinolaryngology, Helsinki, Finland.

3 North Carelian Central Hospital, Department of Dermatology, Joensuu, Finland.

Reprint requests to: Dr Markku Vanhanen, Finnish Institute of Occupational Health, Topeliuksenkatu 41 a A, SF-00250 Helsinki, Finland. [E-mail: markku.vanhanen@occuphealth.fi] 
cellulase enzyme using inhalation challenge in an exposure chamber.

\section{Subjects and methods}

\section{Subjects}

Eleven workers with symptoms at work were referred to the Finnish Institute of Occupational Health. Four of them were working in the enzyme production departments of an enzyme factory, 3 in the laboratory of the factory, and 4 in a plant which was spray-drying cellulase on a subcontract basis. Exposure to enzyme liquids and aerosols was possible during the fermentation process and in subsequent filtration and concentration processes. Exposure to powdered products occurred during the spray-drying of enzymes and during the packing of the dry products. In the laboratory, both liquid and dry cellulase preparations were handled routinely, usually without respiratory protection. Use of protection was inconsistent even among the processmen. Table 1 summarizes the data on the age, gender, exposure time, smoking, skin prick tests, and pulmonary function of the patients. Suspected occupational asthma or rhinitis was confirmed for all 11 of the workers.

\section{Skin prick tests}

As test enzymes, 2 commercial fungal cellulases (Multifect CS $®$, Genencor International, Finland, and Econase CEP(), Alko Ltd, Finland), 2 fungal xylanases (Xylanase $250 \AA$, Ueda Chemical Industrial Co, Ltd, Japan, and Ecopulp ${ }^{\circledR}$, Alko Ltd), all of Trichoderma reesei origin, bacterial (Bacillus) $\alpha$-amylase (BAN $1000 \mathrm{~S} \circledast$, Novo Nordisk A/S, Denmark) and fungal (Aspergillus) $\alpha$-amylase (Sal Conc ${ }^{\circledR}$, Shin Nihhon, Japan) were used in the skin prick testing. The test solutions were prepared and the tests performed as described by Vanhanen et al (17). In the determination of the atopic status, common environmental inhalant allergens were used (cat, dog, timothy, birch, alder, mugwort and house dust mite, Allergologisk Laboratorium A/S, ALK, Copenhagen, Denmark). A person was defined as atopic if he or she had a positive skin prick test to $\geq 1$ of the environmental allergens. Additional prick tests (eg, with flours) were performed according to individual exposure histories and symptoms. Histamine hydrochloride $(10 \mathrm{mg} / \mathrm{ml})$ was used as a positive control.

\section{Measurements of immunoglogulin $E$}

Specific immunoglogulin $\mathrm{E}(\mathrm{IgE})$ antibodies to enzymes were determined with the radioallergosorbent test (RAST). Proteins of commercial enzyme preparations

Table 1. Personal data, exposure time, smoking, skin prick test results, and lung function of the 11 patients.

\begin{tabular}{|c|c|c|c|c|c|c|c|c|c|c|c|c|c|}
\hline \multirow[t]{3}{*}{$\begin{array}{l}\text { Patient } \\
\text { number }\end{array}$} & \multirow[t]{3}{*}{$\begin{array}{c}\text { Age } \\
\text { (years) }\end{array}$} & \multirow[t]{3}{*}{ Gender } & \multirow[t]{3}{*}{$\begin{array}{l}\text { Task, exposure } \\
\text { time before symptoms }\end{array}$} & \multirow[t]{3}{*}{ Smoking } & \multicolumn{2}{|c|}{$\begin{array}{l}\text { Positive skin } \\
\text { prick tests }\end{array}$} & \multicolumn{6}{|c|}{ Spirometry } & \multirow{3}{*}{$\begin{array}{l}\text { Bronchial } \\
\text { hyperre- } \\
\text { activity, } \\
\mathrm{PD}_{15}{ }^{2}\end{array}$} \\
\hline & & & & & \multirow[t]{2}{*}{$\begin{array}{l}\text { Environmental } \\
\text { allergens, others }\end{array}$} & \multirow[t]{2}{*}{ Enzymes } & \multicolumn{3}{|c|}{$\begin{array}{c}\text { Forced ventilatory } \\
\text { capacity }\end{array}$} & \multicolumn{3}{|c|}{$\begin{array}{l}\text { Forced expiratory } \\
\text { volume in } 1 \mathrm{~s}\end{array}$} & \\
\hline & & & & & & & $\begin{array}{l}\text { Mea- } \\
\text { sured } \\
\text { value }\end{array}$ & $\begin{array}{l}\text { Refer- } \\
\text { ence } \\
\text { value }\end{array}$ & $\begin{array}{c}\text { Per- } \\
\text { cent } \\
\text { normal }\end{array}$ & $\begin{array}{l}\text { Meas- } \\
\text { sured } \\
\text { value }\end{array}$ & $\begin{array}{l}\text { Refer- } \\
\text { ence } \\
\text { value }\end{array}$ & $\begin{array}{c}\text { Per- } \\
\text { cent } \\
\text { normal }\end{array}$ & \\
\hline 1 & 46 & Male & $\begin{array}{l}\text { Foreman in mainte- } \\
\text { nance, } 4 \text { years }\end{array}$ & No & $\begin{array}{l}\text { Timothy, } \\
\text { mugwort, barley }\end{array}$ & $\begin{array}{l}\text { Cellulase, } \\
\text { xylanase }\end{array}$ & 5.87 & 5.20 & 114 & 3.96 & 4.08 & 97 & $\begin{array}{l}\text { Yes, } \\
0.70 \mathrm{mg}\end{array}$ \\
\hline 2 & 30 & Male & $\begin{array}{l}\text { Processman, } \\
3 \text { years }\end{array}$ & Yes & $\begin{array}{l}\text { Birch, alder, } \\
\text { timothy }\end{array}$ & $\begin{array}{l}\text { Cellulase, } \\
\text { xylanase }\end{array}$ & 5.33 & 5.13 & 104 & 3.82 & 4.15 & 92 & $\begin{array}{l}\text { Yes, } \\
0.49 \mathrm{mg}\end{array}$ \\
\hline 3 & 30 & Female & $\begin{array}{l}\text { Laboratory assistant } \\
5 \text { years }\end{array}$ & No & Negative & $\begin{array}{l}\text { Cellulase, } \\
\text { xylanase }\end{array}$ & 3.69 & 4.05 & 91 & 2.89 & 3.52 & 82 & No \\
\hline 4 & 37 & Female & $\begin{array}{l}\text { Cleaner, laboratory } \\
\text { assistant, } 5 \text { years }\end{array}$ & Yes & House dust mite & $\begin{array}{l}\text { Cellulase, } \\
\text { xylanase }\end{array}$ & 3.91 & 4.20 & 93 & 3.12 & 3.50 & 89 & No \\
\hline 5 & 24 & Female & $\begin{array}{l}\text { Laboratory assistant, } \\
0.5 \text { years }\end{array}$ & No & Negative & $\begin{array}{l}\text { Cellulase, } \\
\text { xylanase }\end{array}$ & 5.08 & 4.57 & 111 & 3.92 & 4.00 & 98 & No \\
\hline 6 & 40 & Male & $\begin{array}{l}\text { Processman, } \\
10 \text { years }\end{array}$ & No & $\begin{array}{l}\text { Cat, mugwort, } \\
\text { rye, barley }\end{array}$ & Cellulase & 5.61 & 5.24 & 107 & 4.61 & 4.30 & 107 & $\begin{array}{l}\text { Yes, } \\
0.98 \mathrm{mg}\end{array}$ \\
\hline 7 & 47 & Male & Processman, 3 years & No & Negative & Negative & 5.09 & 4.89 & 104 & 3.57 & 3.92 & 91 & No \\
\hline 8 & 40 & Female & $\begin{array}{l}\text { Packer, } \\
5 \text { years }\end{array}$ & No & Negative & Cellulase & 3.66 & 3.77 & 97 & 2.78 & 3.16 & 88 & $\begin{array}{l}\text { Yes, } \\
<0.10 \mathrm{mg}\end{array}$ \\
\hline 9 & 41 & Female & $\begin{array}{l}\text { Laboratory assistant, } \\
4 \text { years }\end{array}$ & No & Birch, timothy & $\begin{array}{l}\text { Cellulase, } \\
\text { xylanase }\end{array}$ & 4.06 & 4.14 & 98 & 3.18 & 3.42 & 93 & $\begin{array}{l}\text { Yes, } \\
0.45 \mathrm{mg}\end{array}$ \\
\hline 10 & 36 & Female & $\begin{array}{l}\text { Cleaner, } \\
1 \text { years }\end{array}$ & Yes & $\begin{array}{l}\text { Cat, birch, } \\
\text { timothy }\end{array}$ & $\begin{array}{l}\text { Cellulase, } \\
\text { xylanase }\end{array}$ & 3.35 & 3.38 & 99 & 2.89 & 3.44 & 84 & $\begin{array}{l}\text { Yes, } \\
<0.1 \mathrm{mg}\end{array}$ \\
\hline 11 & 31 & Female & $\begin{array}{l}\text { Laboratory assistant, } \\
3 \text { years }\end{array}$ & No & $\begin{array}{l}\text { Birch, timothy, } \\
\text { wheat }\end{array}$ & Cellulase & 5.37 & 4.63 & 116 & 4.21 & 3.93 & 107 & $\begin{array}{l}\text { Yes, } \\
0.52 \mathrm{mg}\end{array}$ \\
\hline
\end{tabular}

a $\mathrm{PD}_{15}=$ provocative dose of histamine inducing a $15 \%$ drop in forced expiratory volume in 1 second. 
were conjugated to cyanogen-bromide-activated paper discs using the method of Ceska et al (18). Other reagents were obtained for RAST from Phadebas RAST kits (Pharmacia, Sweden). The results, in kilounits per liter, were based on the RAST reference serum of Pharmacia. Values of $>0.35 \mathrm{kU} / \mathrm{l}$ were defined as positive, indicating sensitization.

\section{Lung function tests}

The spirograms were recorded with a Medikro 101 spirometer (Medikro Oy, Finland). Bronchial hyperreactivity was assessed with the histamine challenge test described by Sovijärvi (19) using an automatic dosimetric inhaler. The $\mathrm{PD}_{15}$ [provocative dose of histamine inducing a $15 \%$ drop in forced expiratory volume in 1 second $\left.\left(\mathrm{FEV}_{1.0}\right)\right]$ was calculated. Bronchial hyperreactivity was confirmed if the $\mathrm{PD}_{15}$ was $\leq 1.60 \mathrm{mg}$.

\section{Challenge tests}

Inhalation challenges were carried out with powder-form cellulase (Econase $\mathrm{CEP} 囚$ ) in a $6-\mathrm{m}^{3}$ ventilated exposure chamber. The protein content of the cellulase preparation was $0.77 \mathrm{mg} / \mathrm{mg}$, of which $70-80 \%$ was enzyme protein, according to the information given by the manufacturer. The cellulase was mixed with lactose powder in varying concentrations. Four different enzyme-lactose

Table 2. Cellulase and total dust concentrations in the air during 5 challenge tests with cellulase.

\begin{tabular}{|c|c|c|c|c|}
\hline \multirow[t]{2}{*}{$\begin{array}{l}\text { Challenge test, } \\
\text { cellulase }\end{array}$} & \multicolumn{2}{|c|}{$\begin{array}{c}\text { Cellulase air } \\
\text { concentration } \\
\mu \mathrm{g} / \mathrm{m}^{3}\end{array}$} & \multicolumn{2}{|c|}{$\begin{array}{c}\text { Total dust } \\
\text { air concentration } \\
\mathrm{mg} / \mathrm{m}^{3}\end{array}$} \\
\hline & Test 1 & Test 2 & Test 1 & Test 2 \\
\hline $\begin{array}{l}\text { Cellulase, } 30 \mathrm{mg} \\
\text { Cellulase, } 300 \mathrm{mg} \\
\text { Cellulase, } 3 \mathrm{~g}\end{array}$ & $\begin{array}{r}1 \\
25 \\
1300\end{array}$ & $\begin{array}{r}6 \\
140\end{array}$ & $\begin{array}{l}45 \\
36 \\
53\end{array}$ & $\begin{array}{l}45 \\
45\end{array}$ \\
\hline
\end{tabular}

mixtures were used in the challenges. At the lowest level, $30 \mathrm{mg}$ of cellulase was mixed with $100 \mathrm{~g}$ of lactose, which equals $0.03 \%$ in weight. The predicted air concentration of cellulase was calculated to be $1-5 \mu \mathrm{g} / \mathrm{m}^{3}$. At the next consecutive levels, a 10 -fold increase in cellulase was used up to $3 \mathrm{~g}$ of cellulase in the total amount of $100 \mathrm{~g}$ of the lactose-cellulase mixture. The maximum exposure, in 2 cases, was $10 \mathrm{~g}$ of cellulase. The mixture was placed in a bowl and the enzyme dust was generated with serial impacts, every 60 seconds, of pressurized air from a nozzle over the bowl. The placebo test with lactose was carried out with the same procedure for all the patients, except 1 , for whom a formaldehyde challenge was performed. The challenges lasted for $30 \mathrm{~min}-$ utes, but they were interrupted earlier if necessary because of symptoms. The peak expiratory flow (PEF) was recorded according to the method of Newman Taylor \& Venables (20), with a Wright peak flow meter every 15 minutes during the challenge, and afterwards every $1-$ 4 hours until the end of 24 hours. The diurnal PEF curves of the unexposed days were used for reference.

Air samples were taken during 5 challenge tests for measurement of the total dust and enzyme dust. The samples were taken for the total dust measurement with a standardized method by stationary sampling near the breathing zone of the patient at a flow rate of $201 / \mathrm{min}$ and with the use of 37-mm Millipore AA filters for the gravimetric determination of the dust. For the determination of the cellulase air concentration, high-volume sampling (GMW Handi-Vol 2000) at a flow rate of 25 $\mathrm{m}^{3} / \mathrm{h}$ and glass fiber filters (Whatman $\mathrm{GF} / \mathrm{C}$ ) were used. The enzyme content of the sample was determined by a method based on monoclonal antibodies, using dot-blot techniques (21). In the challenge tests, cellobiohydrolase I (CBH I), which accounts for $60-80 \%$ of the cellulase complex (22), was measured. The method of analysis has been described in detail elsewhere (17).

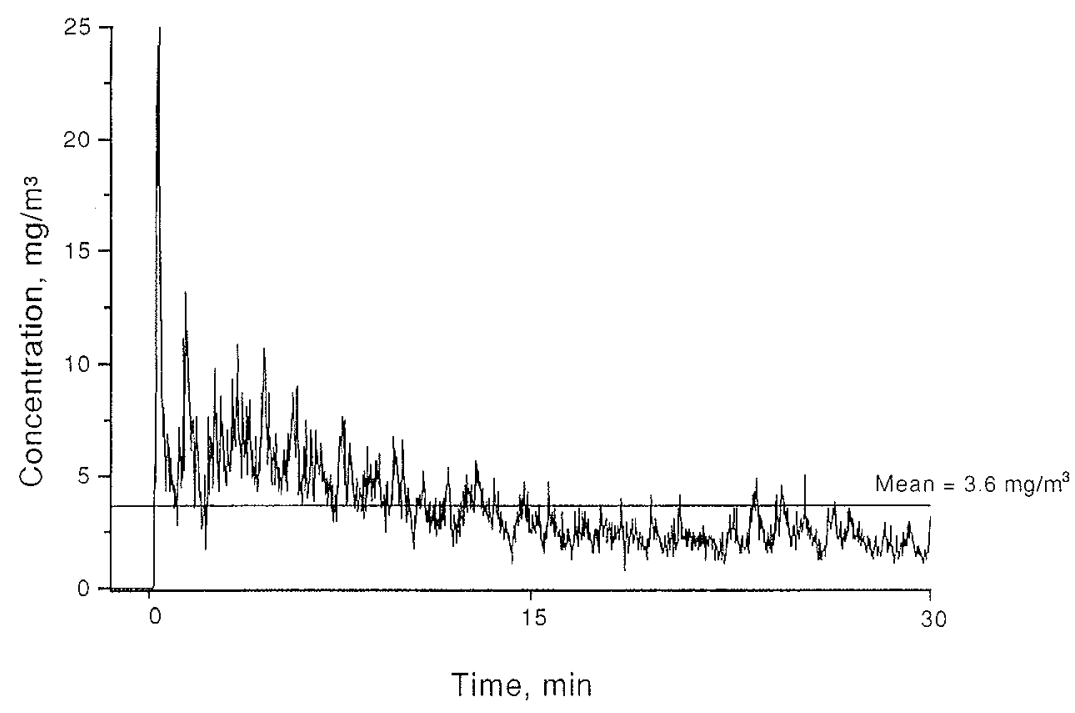

Figure 1. Variation of the aerosol concentration during the 30-minute challenge period, as measured by a light scattering photometer (Hund). 


\section{Follow-up of rhinolaryngological, skin and eye symptoms and their status}

The rhinolaryngological status was recorded prior to and after the challenge by a specialist in otorhinolaryngology $(\mathrm{MH})(23)$, and the skin status was determined by a dermatologist (KT, LK). Eye symptoms were recorded by a nurse or a physician.

\section{Results}

\section{Enzyme concentrations}

The cellulase and total dust measurements were performed in 2 challenges with $30 \mathrm{mg}$ of cellulase, in 2 challenges with $300 \mathrm{mg}$ of cellulase, and in 1 challenge with $3 \mathrm{~g}$ of cellulase. The results of the dust measurements are summarized in table 2 . These results, as well as the enzyme results, correspond to the time average values of the 30-minute sampling period. The concentration of total dust varied from 36 to $53 \mathrm{mg} / \mathrm{m}^{3}$. The concentrations of cellulase showed an increase which followed reasonably well the dilution ratio of the lactose powder, ranging from $1 \mu \mathrm{g} / \mathrm{m}^{3}$ to $1.3 \mathrm{mg} / \mathrm{m}^{3}$.

For an example of the pattern of the lactose dust concentration during the challenges, measurements were carried out with a direct-reading aerosol monitor (Hund, Germany) placed at the breathing zone height of a person during the challenge test. A typical pattern is shown in figure 1. Some exposure data from the workplaces were available from the industrial hygiene surveillance program of the plants. From laboratory work of the plant, the measurements showed a CBH I concentration of $40-$ $80 \mathrm{ng} / \mathrm{m}^{3}$. In the plant where cellulase was spray-dried and packed, concentrations up to 120 and $6-7 \mu \mathrm{g} / \mathrm{m}^{3}$ were measured during the spray-drying and packing, respectively (7).

\section{Challenge tests}

Table 3 summarizes the data obtained on the enzyme test reactions and the symptoms at work and also the details of the challenge tests. Eight of the patients had PEF drops

Table 3. Enzyme sensitization, symptoms at work, challenge test settings, and symptoms in the tests. $(\mathrm{ND}=$ not done, SPT $=$ skin prck test, $R A S T=$ radioallergosorbent test, $P E F=$ peak expiratory flow)

\begin{tabular}{|c|c|c|c|c|c|}
\hline \multirow[t]{2}{*}{$\begin{array}{l}\text { Patient } \\
\text { number }\end{array}$} & \multicolumn{2}{|c|}{$\begin{array}{l}\text { Sensitization to cellulase or } \\
\text { xylanase }\end{array}$} & \multirow[t]{2}{*}{ Symptoms at work } & \multicolumn{2}{|c|}{ Challenge test with cellulase } \\
\hline & SPT & RAST, kU/l & & $\begin{array}{l}\text { Amount } \\
\text { of } \\
\text { cellulase }\end{array}$ & Symptoms and findings at challenge \\
\hline 1 & $\begin{array}{l}\text { Cellulase }+, \\
\text { xylanase }+\end{array}$ & $\begin{array}{l}\text { Cellulase } 2.3 \\
\text { xylanase }<0.3\end{array}$ & Rhinorrhea, hoarseness, dyspnea & $\begin{array}{l}30 \mathrm{mg} \\
300 \mathrm{mg} \\
10 \mathrm{~g}\end{array}$ & $\begin{array}{l}\text { No symptoms } \\
\text { Rhinorrhea, pharyngeal edema } \\
\text { Pharyngeal edema, dual asthma reaction, PEF drop } 36 \%\end{array}$ \\
\hline 2 & $\begin{array}{l}\text { Cellulase }+ \\
\text { xylanase }+\end{array}$ & $\begin{array}{l}\text { Cellulase }>17.5 \\
\text { xylanase }>17.5\end{array}$ & Rhinorrhea, hoarseness, dyspnea & $30 \mathrm{mg}$ & $\begin{array}{l}\text { Pharyngeal redness, slight edema, immediate } \\
\text { PEF drop } 17 \%\end{array}$ \\
\hline 3 & $\begin{array}{l}\text { Cellulase }+ \\
\text { xylanase }+\end{array}$ & $\begin{array}{l}\text { Cellulase }<0.3 \\
\text { xylanase }<0.3\end{array}$ & Rhinorrhea & $\begin{array}{l}300 \mathrm{mg} \\
3 \mathrm{~g}\end{array}$ & $\begin{array}{l}\text { No symptoms } \\
\text { Rhinorrhea, nasal blockage, PEF drop 15\% }\end{array}$ \\
\hline 4 & $\begin{array}{l}\text { Cellulase }+ \\
\text { xylanase }+\end{array}$ & $\begin{array}{l}\text { Cellulase } 3.1 \\
\text { xylanase } 0.5\end{array}$ & $\begin{array}{l}\text { Rhinorrhea, hoarseness, conjunctival } \\
\text { irritation, edema of eyelids }\end{array}$ & $30 \mathrm{mg}$ & $\begin{array}{l}\text { Rhinorrhea, nasal blockage, edema of eyelids, } \\
\text { redness of tace }\end{array}$ \\
\hline 5 & $\begin{array}{l}\text { Cellulase } t \text {, } \\
\text { xylanase }+\end{array}$ & $\begin{array}{l}\text { Cellulase } 2.6 \text {, } \\
\text { xylanase } 5.4\end{array}$ & $\begin{array}{l}\text { Nasal stuffiness, redness of face, } \\
\text { neck and arms }\end{array}$ & $30 \mathrm{mg}$ & Rhinorrhea, nasal blockage \\
\hline 6 & $\begin{array}{l}\text { Cellulase +, } \\
\text { xylanase - }\end{array}$ & $\begin{array}{l}\text { Cellulase } 1.5 \\
\text { xylanase }<0.3\end{array}$ & $\begin{array}{l}\text { Nasal stuffiness, hoarseness, } \\
\text { dyspnea, whealing of upper arms }\end{array}$ & $\begin{array}{l}30 \mathrm{mg} \\
300 \mathrm{mg} \\
3 \mathrm{~g}\end{array}$ & $\begin{array}{l}\text { No symptoms, PEF drop } 18 \% \\
\text { No symptoms, PEF drop } 14 \% \\
\text { Rhinorrhea, nasal blockage, dyspnea, PEF drop } 31 \%\end{array}$ \\
\hline 7 & $\begin{array}{l}\text { Cellulase -, } \\
\text { xylanase - }\end{array}$ & $\begin{array}{l}\text { Cellulase }<0.3 \\
\text { xylanase }<0.3\end{array}$ & $\begin{array}{l}\text { Cough, dyspnea when handling } \\
\text { cellulase enzymes }\end{array}$ & $\begin{array}{l}3 \mathrm{~g} \\
0 \mathrm{~g}\end{array}$ & $\begin{array}{l}\text { No symptoms, PEF drop } 13 \% \\
\text { Dyspnea, PEF drop } 23 \%\end{array}$ \\
\hline 8 & $\begin{array}{l}\text { Cellulase +, } \\
\text { xylanase - }\end{array}$ & $\begin{array}{l}\text { Cellulase }<0.3 \\
\text { xylanase }<0.3\end{array}$ & $\begin{array}{l}\text { Asthma symptoms } 1 \text { year prior to } \\
\text { current work; work-related asthma } \\
\text { symptoms started after about } 5 \\
\text { years of employment }\end{array}$ & $\begin{array}{l}30 \mathrm{mg} \\
300 \mathrm{mg}\end{array}$ & $\begin{array}{l}\text { Cough, PEF drop } 15 \% \\
\text { Dyspnea, PEF drop } 30 \%\end{array}$ \\
\hline 9 & $\begin{array}{l}\text { Cellulase }+ \\
\text { xylanase }+\end{array}$ & $\begin{array}{l}\text { Cellulase } 2.5 \\
\text { xylanase } 0.6\end{array}$ & Dyspnea & $\begin{array}{l}30 \mathrm{mg} \\
300 \mathrm{mg}\end{array}$ & $\begin{array}{l}\text { No symptoms } \\
\text { Rhinorrhea, dyspnea; skin on face red and swollen, } \\
\text { PEF drop } 15 \%\end{array}$ \\
\hline 10 & $\begin{array}{l}\text { Cellulase }+ \\
\text { xylanase }+\end{array}$ & $\begin{array}{l}\text { Cellulase }>17.5 \\
\text { xylanase }>17.5\end{array}$ & $\begin{array}{l}\text { Dyspnea from pollen for some years; } \\
\text { asthma diagnosis } 1 \text { year prior to } \\
\text { current work; urticaria, rhinorrhea and } \\
\text { increasing asthma symptoms at work } \\
\text { after } 1 \text { year of employment }\end{array}$ & $\begin{array}{l}30 \mathrm{mg} \\
300 \mathrm{mg}\end{array}$ & $\begin{array}{l}\text { No symptoms } \\
\text { Dyspnea, rhinorrhea, PEF drop } 24 \%\end{array}$ \\
\hline 11 & $\begin{array}{l}\text { Cellulase }+ \\
\text { xylanase ND }\end{array}$ & $\begin{array}{l}\text { Cellulase }>17.5 \\
\text { xylanase ND }\end{array}$ & $\begin{array}{l}\text { Rhinorrhea and occasional dyspnea } \\
\text { due to pollen for some years, then } \\
\text { increasing rhinorrhea and occasional } \\
\text { dyspnea at work after } 3 \text { years of } \\
\text { employment }\end{array}$ & $\begin{array}{l}30 \mathrm{mg} \\
300 \mathrm{mg}\end{array}$ & $\begin{array}{l}\text { No symptoms } \\
\text { Rhinorrhea }\end{array}$ \\
\hline
\end{tabular}


of more than $15 \%$ in the challenges, 8 had rhinorrhea, 2 had pharyngeal symptoms, and 2 had skin symptoms. In patient 10 the skin symptoms were not elicited in the chamber challenge, but could be repeated with a local skin provocation test with the solution of the skin prick test. The skin symptoms of patient 6 have been described in more detail by Kanerva et al (24).

The spectrum of symptoms at work and in the challenges, as well as the enzyme concentrations at which each symptom was elicited, varied. Four patients showed symptoms at the lowest exposure level $(30 \mathrm{mg}$ cellulase), 4 had them at the 2 nd level ( $300 \mathrm{mg}$ cellulase), 2 were affected at the $3 \mathrm{rd}$ level $(3 \mathrm{~g})$, and 1 reached the 4th level (10 g cellulase) before showing symptoms. There seemed to be an association with the level of sensitization, as assessed by the RAST value, and with the amount of enzyme needed to elicit the symptoms in the challenges. The patients with high RAST values (patients 2, 10 and 11) responded to either $30 \mathrm{mg}$ or $300 \mathrm{mg}$ of cellulase, while the 2 RAST-negative patients responded to only $3 \mathrm{~g}$ or $10 \mathrm{~g}$.

Patient 1 was the 1 st to whom this cellulase challenge method was applied (25). The cellulase challenge was started with $10 \mathrm{~g}$ of cellulase, which resulted in severe edema on the posterior wall and lateral bands of the pharynx and uvula, cough, and a dual asthmatic reaction. [The pharyngeal findings have been described in detail previously (25).] The patient was symptomless at the control 7 months later. He was still working at the same plant, where occasional exposure to cellulase could not be excluded. An attempt was made to assess the concentration which would not elicite symptoms. A challenge test of $300 \mathrm{mg}$ of cellulase caused rhinorrhea, nasal blockage and edema of the pharynx, but no drop in PEF.

\section{Discussion}

Eleven patients with respiratory symptoms during work in which they were exposed to cellulolytic enzymes were examined with inhalation challenge tests. Ten of the patients were sensitized to cellulase according to the skin prick tests, and 9 of these were also RAST positive. We do not know why 1 of the patients was negative in the skin prick test and the RAST, yet presented a positive response in the challenge test. The concentration of antigen used in the skin prick test and the RAST may have been too low for this person. One explanation could be that he had non-IgE-mediated asthma. Nevertheless, his symptoms at work were connected with exposure to cellulase and could be repeated by a challenge test. We used the commercial cellulase preparation in the challenges to which the workers were exposed. As these preparations need not be purified with respect to the cellulase protein, they contain also other enzyme activities produced by the microbe, as well as stabilizers (usually salts) and traces of the culture media. Thus the exact causative components of these rather impure enzyme products were not always known.

In the first challenge test with cellulase, conducted with patient 1, 10 grams of cellulase were diluted with lactose at a ratio of 1:10. This concentration was considered to be realistic to reveal the symptoms. However, it appeared to be too large for this patient. Later, the challenges were started at lower levels, depending on the severity of the symptoms and the degree of sensitization, as indicated by the RAST value.

A PEF drop of $\geq 15 \%$ was considered significant in cases with sensitization to the enzyme if the reactions in the challenges were immediate and the symptoms elicited were identical to those experienced at work. Furthermore, as the challenge procedure with cellulase was new and unexpectedly strong reactions could not be excluded with certainty, as had been the case with patient 1 , higher exposure levels, to achieve a greater drop, were considered unethical. At the time of this study the present routine for measuring $\mathrm{FEV}_{1.0}$ was not in use; therefore, the follow-up was performed with PEF measurements.

It is noteworthy that some of our patients had symptoms of the upper respiratory tract only. These symptoms are easily overlooked. Our challenge method was able to pick up these symptoms, also the pharyngeal changes. Five of our patients had skin symptoms at work, but only 2 showed skin symptoms during the challenge test. Nevertheless, the symptoms may reflect specific IgE-mediated contact urticaria that appeared more readily at work, where other work-related irritants and sweating may have enhanced the skin penetration of the allergens.

The measured cellulase air concentrations agreed rather well with the values predicted from the total dust values and the mixing ratio of the cellulase and lactose. Thus a protocol with increasing levels of exposure could be established. The measured cellulase concentrations showed relatively great variation between the consecutive tests at powder dilutions of $30 \mathrm{mg} / 100 \mathrm{~g}$ and 300 $\mathrm{mg} / 100 \mathrm{~g}$, while the total dust concentration indicated less variation. There may be several reasons for this variation. The analysis of cellulase was semiquantitative, the reading of the result having been based on visual comparison of the colored dots of the samples with the dots of standard series at a dilution ratio of 1:2. Incomplete mixing of the cellulase and lactose powders is another possible, though not probable, explanation for the variation. The precision of the method could be improved by continuous generation of the dust in the chamber, which would also eliminate high concentration peaks in the beginning of the exposure period. The starting level and the higher levels of concentration were apparently sufficient to elicit the symptoms experienced at work even in the 
relatively short exposure time. We have no data on the particle size distribution of the lactose-cellulase aerosol, but the total dust level of $40-50 \mathrm{mg} / \mathrm{m}^{3}$ can be estimated to correspond to $5-20 \mathrm{mg} / \mathrm{m}^{3}$ of respirable dust (26).

The results obtained from measurements with the direct-reading instrument revealed a concentration variation with a short high peak in the beginning and a constantly decreasing level to approximately the middle of the challenge period when it stabilized at about $2 \mathrm{mg} /$ $\mathrm{m}^{3}$. The exposure level was proper and did not show unacceptable variation or transient peaks that were too high, as has been shown to appear during traditional challenges when powder is tipped from one tray to another (26). Even the starting peak could be avoided by not letting the patient enter the chamber until 1 minute after the generation of the dust. We deemed this procedure unnecessary, however.

The challenge method used by us simulates the exposure conditions at the worksite, which is an advantage over methods in which the enzyme is inhaled from capsules through inhalers or enzyme aerosol is generated through nebulizers. The enzyme dust generated in the challenge is referable to the dust at the worksite, and, accordingly, the enzyme measurements can be compared with those at the worksite. This procedure improves the safety of the challenge tests. Experiences with the challenge tests can also be transferred to work, when symptoms at work and the sufficiency of industrial hygienic improvements are being assessed. We started with an estimated level of $1 \mu \mathrm{g} / \mathrm{m}^{3}$. This level was based on our knowledge of the contents of the cellulase preparation and also our knowledge about some enzyme air concentrations at different workplaces and the symptoms experienced by the sensitized workers in these circumstances, as demonstrated by air monitoring. We do not know whether these data are directly applicable to other cellulase preparations, but the challenge levels with them can be estimated according to the same principles.

\section{Acknowledgments}

Ms Terttu Mäkelä and the staff at the patient ward of the Finnish Institute of Occupational Health are thanked for their skillful technical assistance.

\section{References}

1. Gerhartz W, editor. Enzymes in industry. Weinheim (Germany): VCH Verlagsgesellshaft, 1990.

2. Brisman J. Industrial enzymes: the Nordic expert group for criteria documentation of health risks from chemicals. Solna (Sweden): Arbetsmiljöinstitutet, 1994. Arbete och Hälsa 28.
3. Ransom JH, Schuster M. Allergic reaction to enzymes used in plant cloning experiments. J All Clin Immunol 1981; 67:5:412-5.

4. Losada E, Hinojosa M, Moneo I. Occupational asthma caused by cellulase. J All Clin Immunol 1986;77:635-9.

5. Tarvainen K, Kanerva L, Tupasela O, Grenguist-Nordén B, Jolanki R, Estlander T, et al. Allergy from cellulase and xylanase enzymes. Clin Exp Allergy 1991;21:609-15.

6. Quirce S, Cuevas M, Luz Diez-Gomez M, Fernandez-Rivas M, Hijonosa M, Gongales R, et al. Respiratory allergy to Aspergillus-derived enzymes in bakers' asthma. J Allergy Clin Immunol 1992;90:970-8.

7. Vanhanen M, Tuomi T, Nordman H, Tupasela O, Holmberg $\mathrm{PC}$, Miettinen M, et al. Sensitization to industrial enzymes in enzyme research and production. Scand J Work Environ Health 1997;23:385-91.

8. Cartier A, Malo J-L. Occupational challenge tests. In: Bernstein IL, Chan-Yeung M, MaloJ-L, Bernstein DI, editors. Asthma in the Workplace. New York (NY): Marcel Dekker Inc, 1999:211-33.

9. Merget R, Stollfuss J, Wiewrodt R, Fruhauf H, Koch U, Bolm-Audorff $U$, et al. Respiratory pathophysiologic responses: diagnostic tests in enzyme allergy. J Allergy Clin Immunol 1993;92:264-77.

10. Pepys J, Hargreave FE, Longbottom LJ, Faux J. Allergic reaction of the lung to enzymes of Bacillus subtilis. Lancet $1969 ; 1: 1181-4$.

11. Baur X, König G, Bencze K, Fruhmann G. Clinical symptoms and results of skin test, RAST and bronchial provocation test in thirty-three papain workers: evidence for strong immunogenic potency and clinically relevant "proteolytic effects of airborne papain". Clin Allergy 1982;12:9-17.

12. Carmona BJG, Picon JS, Sotilles GM. Occupational asthma in bakeries caused by sensitivity to alpha-amylase. Allergy 1991;46:274-6.

13. Losada E, Hijonosa M, Quirce S, Sánchez-Cano M, Moneo I. Occupational asthma caused by alpha-amylase inhalation: Clinical and immunologic findings and bronchial response patterns. J Allergy Clin Immunol 1992;89:118-25.

14. Zetterström $\mathrm{O}$. Challenge and exposure test reactions to enzyme detergents in subjects sensitized to subtilisin. Clin Allergy 1977;7:355-63.

15. Aiken TC, Ward R, Peel ET, Hendrick DJ. Occupational asthma due to porcine pancreatic amylase. Occup Environ Med 1997;54:762-4.

16. Brisman J, Belin L. Clinical and immunological responses to occupational exposure to alpha-amylase in the baking industry. Br J Ind Med 1991;48:604-8.

17. Vanhanen $\mathrm{M}$, Tuomi $\mathrm{T}$, Hokkanen $\mathrm{H}$, Tupasela $\mathrm{O}$, Tuomainen A, Holmberg PC, et al. Enzyme exposure and enzyme sensitization in the baking industry. Occup Environ Med 1996; 53:670-6.

18. Ceska M, Eriksson R, Varga JM. Radioimmunosorbent assay of allergens. J Allergy Clin Immunol 1972;49:1—9.

19. Sovijärvi ARA, Malmberg P, Reinikainen K, Rytilä P, Poppius H. A rapid dosimetric method with controlled tidal breathing for histamine challenge: repeatibility and distribution of bronchial reactivity in a clinical material. Chest 1993;104:164-71.

20. Newman Taylor AJ, Venables KM. Clinical and epidemiological methods in investigating occupational asthma. In: PEPYS $\mathrm{J}$, editor. Clinics in immunology and allergy: occupational respiratory allergy, volume 4 . Philadelphia (MA): WB Saunders, $1984: 3-17$. 
21. Hawkes R, Niday E, Gordon JA. Dot-Immunobinding assay for monoclonal and other antibodies. Anal Biochem 1982;199:142-7.

22. Harkki A, Mäntylä A, Penttilä M, Muttilainen S, Buhler R, Suominen $P$, et al. Genetic engineering of Trichoderma to produce strains with novel cellulase profiles. Enzyme Microbiol Technol 1991;13:227-33.

23. Hytönen $M$, Sala E. Nasal provocation test in the diagnostics of occupational allergic rhinitis. Rhinology 1996;34:86-90.

24. Kanerva L, Vanhanen M, Tupasela O. Occupational contact urticaria from cellulase enzyme. Contact Dermatitis
1998;38:176-7.

25. Hytönen M, Vanhanen M, Nordman H, Keskinen H, Tuomi T, Tupasela $O$. Pharyngeal edema caused by occupational exposure to cellulase enzyme. Allergy 1994;49:782-4.

26. Cloutier Y, Lagier F, Lemieux R, Blais MC, St-Arnaud C, Cartier A, et al. New methodology for specific inhalation challenges with occupational agents in powder form. Eur Respir J 1989;2:769—77.

Received for publication: 23 April 1999 